\title{
Evaluation of rosemary extract effectiveness in the technology of meat-containing sausages with duck meat
}

\author{
Nataliia Bozhko', Vasyl Tischenko ${ }^{1}$, \\ Liudmyla Baidak ${ }^{1}$, Vasyl Pasichnyi ${ }^{2}$
}

\author{
1 - Sumy National Agrarian University, Sumy, Ukraine \\ 2 - National University of food Technologies, Kyiv, Ukraine
}

\section{Keywords:}

Antioxidant

Extract

Rosemary

Sausages

Duck

\section{Article history:}

Received

02.02.2018

Received in revised form 19.02.2018

Accepted 29.03.2018

Corresponding

author:

Vasyl Pasichnyi

E-mail:

pasww1@ukr.net

DOI:

$10.24263 / 2304-$

974X-2018-7-1-6

\section{Abstract}

Introduction. The objective of this research was to evaluate the effectiveness of using rosemary extract in the technology of meatcontaining sausages with duck meat, which is characterized by high content of polyunsaturated fatty acids.

Materials and methods. The formula of meat-containing sausages with duck meat (Cairina moschata), which also included first-grade beef, pork fat, soya protein, milk powder, pork skins protein, soluble fiber FV Fiber, was used as the model for studying rosemary extract effectiveness. The acid value (AV), peroxide value (PV), thiobarbitur acid reactive species (TBARS) were determined during the storage of meat- containing sausages.

Results and discussion. The results of the research indicated that incorporated antioxidant retarded the lipids degradation due to the high concentration of extract flavonoids. The rosemary extract inhibited acylglycerides hydrolytic decomposition most effectively at the concentration of $0.05 \%$. The addition of the rosemary extract helped to slow down the oxidative processes. Among the experimental sausages samples, the peroxide value increased more intensively in the sample without the additive. The addition of the extract at the concentration of $0.05 \%$ had the greatest stabilizing effect. The peroxide value in this sample was $0,015 \pm 0,001 \% \mathrm{~J}_{2}$ at the end of the storage, while in control this figure was $0,026 \pm 0,002 \% \mathrm{~J}_{2}$, which is $57,69 \%$ higher.

The antioxidant action of additives is also demonstrated by the accumulation of mono- and dialdehydes reacting with 2thiobarbituric acid. The investigation of the secondary oxidation products content allowed us to estimate the depth of the oxidative processes occurring in the samples of the sausages stored for 6 days at $+4^{\circ} \mathrm{C}$. The concentration of the secondary oxidation products was the highest in the control sample, while in the experimental samples TBARS was reduced proportionally to the concentration of the added anti-oxidant additive. At the end of the storage period, TBARS in the control sample was $0.269 \pm 0.04 \mathrm{mg}$ $\mathrm{MA} / \mathrm{kg}$ of the finished product, while in the experimental samples this index ranged from $0.231 \pm 0.03$ to $0.184 \pm 0.04 \mathrm{mg} \mathrm{MA} / \mathrm{kg}$. The largest effect was obtained with the additive concentration of $0.05 \%$, which made it possible to reduce the oxidative fat deterioration by almost two times.

Conclusions. The studies confirmed the high antioxidant activity of the rosemary extract and the effective inhibition of the lipid oxidation process in meat-containing sausages with duck meat. 


\section{Introduction}

Meat products are an important source of complete protein that contains essential amino-acids. They are also good sources of many essential substances such as unsaturated fatty acids, vitamins, minerals in human diet. The oxidative stability of meat depends on the balance and interaction of anti- and prooxidant substances, as well as on the content of the substrates susceptible to oxidation, including polyunsaturated fatty acids, cholesterol and others. [1].

However, cellular systems of antioxidant activity are destroyed during the technological processes of meat processing, including the mechanical destruction of muscle tissue during the mincing process in the production of emulsified meat products, such as boiled sausages.

Sausages of the boiled group are emulsified meat products, the structure of which may contain air cavities, which accelerate the oxidation inside the product under the action of the air oxygen. Oxidizing processes affect the quality of the finished product, contribute to the loss of colour, taste, smell and reduce the shelf life.

During the oxidation of fats, various products of degradation are formed: free acids, in particular their trans isomers, oxygen-containing derivatives, aldehydes, ketones, peroxides, many of which are toxic substances. The most common way of solving the problem of the oxidative damage of meat products is the use of the variety of antioxidant food additives that allow the purposeful regulation of the oxidizing processes of the lipid fraction of meat systems $[2,3,4]$.

The use of synthetic antioxidants in the meat industry is more widespread than the use of natural ones, raising many questions concerning their safety. For this reason, the preparations of natural antioxidants, namely extracts of herbs and spices, berries, fruits, etc attract interest. There is certain experience of their use in manufacturing meat and poultry products [5-7].

The antioxidant efficiency of plant extracts is explained by the features of the chemical composition and concentration of biologically active substances, namely, the high total content of phenolic compounds, tannins and free organic acids [8, 9]. One of the perspective antioxidant preparations for the meat industry can be rosemary extract.

The effectiveness of the rosemary extract was found when it was used in the technology of various types of meat products, including natural and minced semi-finished products from pork, beef, sausage made from pork, natural semi-finished products from poultry [10-16].

On the other hand, there is a prospect for using waterfowl meat in the meat processing industry in Ukraine, which, unfortunately, has not spread enough in this country. However, this type of meat could be used by the meat processors as the perspective raw material due to the complex of physical, chemical, functional and technological indicators, nutritional and biological values.

Meat of the Muscovy ducks (Cairina moschata), has a high protein content - 17,2 $\mathrm{g} / 100 \mathrm{~g}$, a relatively low fat content $-17.4 \mathrm{~g} / 100 \mathrm{~g}$, the concentration of mineral elements is $1.3 \mathrm{~g} / 100 \mathrm{~g}$. Studies have shown that meat of Cairina moschata exceeds the ideal protein both in the sum and the content of most essential amino acids. By the sum of essential amino acids protein of duck meat exceeds the ideal protein by $14.7 \%$. Amino acids score of lysine, tryptophan and methionine + cysteine is $126.2 \%, 122.0 \%, 94.2 \%$ ) respectively $[17,18]$.

One of the features and important biological value indicators of duck meat is fatty acid composition of lipids. Unsaturated fatty acids have the highest proportion in total content 
(68.91\%). Oleic acid share comprises $37.1 \%$ among the monounsaturated fatty acids. Among the polyunsaturated fatty acids, linoleic acid predominates (18,10\%). The content of saturated fatty acids is $30,6 \%$, with the largest proportion of palmitic acid (20.80\%) [1921].

Waterfowl meat can be used to improve and develop the technology of meatcontaining products of boiled group but it needs scientific justification. The existing classification of animal products has no justified standards for storage of meat-containing products with the high proportion of meat, which is non-traditional for the production of boiled sausages.

The high content of unsaturated fatty acids in waterfowl meat creates a certain risk of lipid oxidation in the finished products with duck meat during storage, hence, requires additional technological techniques to prevent negative effects. Therefore, the investigation as for justification of meat product quality and safety indicators are the topical issues.

The aim of this study was to evaluate the effect of using the extract of rosemary in the technology of meat-containing sausages with duck meat.

\section{Materials and Methods}

\section{Experimental design}

To carry out the investigation, in the laboratory of Milk and Meat Technologies Department of the Faculty of Food Technologies (SNAU) the recipe for meat-containing sausages with duck meat (Cairina moschata), first-grade beef, pork fat, soya protein, milk powder, pork skins protein, soluble fiber FV Fiber was developed.

The rosemary extract (Food Ingredients Mega Trade, USA) was added to the minced meat. The extract was added to the forcemeat samples according to the following scheme: № 1 - RE 0,03 \%; № 2 - RE 0,04 \%; № 3 - RE $0,05 \%$ to the raw material mass, the forcemeat sample without antioxidants was the control one.

The recommended concentration of antioxidants applied in meat products technology varies from 0,01 to $0,1 \%$ [22-24]. For this reason, the corresponding concentration of rosemary extract was selected with regard for the content of different groups of substances with an antioxidant property and synergetic effect of their combined use.

All the ingredients were mixed for $20 \mathrm{~min}$, and then the mixture was stuffed into the natural casing. The samples were heat processed until they reached the internal temperature of $72^{\circ} \mathrm{C}$. The sausages samples were then rinsed with cooled water and stored at $4^{0} \mathrm{C}$ for 6 days.

Acid and peroxide values (AV and PV), thiobarbituric acid reactive species (TBARS) were the control indicators. The generally accepted methods were used for the definition of these indicators $[25,26]$.

\section{Production of sausages}

Meat-containing sausages were made according to the recipe containing meat of duck (Cairina moschata), first-grade beef, pork fat, soya protein, milk powder, pork skins protein, soluble fiber FV Fiber, salt and spices in the ratios given in Table 1.

The recipe-analogue of boiled sausage "Duck" was taken as a basis [27]. 
Created recipes of sausages with duck meat

\begin{tabular}{|c|c|c|c|c|}
\hline Raw materials & Analogue & Recipe 1 & Recipe 2 & Recipe 3 \\
\hline \multicolumn{5}{|c|}{ Raw unsalted, kg per $100 \mathrm{~kg}$} \\
\hline Duck Pecking & 40 & - & - & - \\
\hline Duck (Cairina moschata) & - & 40 & 45 & 50 \\
\hline Pork fat & 10 & 10 & 10 & 10 \\
\hline Soya protein & - & 10 & 10 & 10 \\
\hline First-class beef & 47 & 10 & 10 & 10 \\
\hline Milk powder & - & 3 & 3 & 3 \\
\hline FV Fiber & - & 2 & 2 & 2 \\
\hline Pork skins protein & - & 25 & 20 & 15 \\
\hline Potato starch & 3 & - & - & - \\
\hline Total & 100 & 100 & 100 & 100 \\
\hline \multicolumn{5}{|c|}{ Spices and materials, g per $100 \mathrm{~kg}$ of unsalted raw materials } \\
\hline Salt & 2,5 & 2,5 & 2,5 & 2,5 \\
\hline $\mathrm{NaNO}_{2}$ & 0,005 & 0,005 & 0,005 & 0,005 \\
\hline Sugar & 0,1 & 0,1 & 0,1 & 0,1 \\
\hline Pepper black & 0,1 & 0,1 & 0,1 & 0,1 \\
\hline Coriander & 0,05 & 0,05 & 0,05 & 0,05 \\
\hline Garlic fresh & 0,2 & 0,2 & 0,2 & 0,2 \\
\hline
\end{tabular}

The production of samples was carried out in accordance with the technology of minced meat with the addition of hydrated soybean isolate and $20 \%$ water [27].

Duck meat and beef are crumbled, cleaned of tendons and comminuted on the gyroscope with the grating orifices diameter $2-3 \mathrm{~mm}$. Soy isolate is preliminarily hydrated in the ratio of the preparation:water $-1: 5$. The pork skins protein is prepared according to the following scheme: cleansing of the skins, cutting into small pieces, cooking in the presence of water in the amount of $50 \%$ at a temperature of $90-95{ }^{\circ} \mathrm{C}$ for $30-40$ minutes, chopping hot with the meat mincer with the grille hole diameter of $2-3 \mathrm{~mm}$. At the same time, auxiliary materials are being prepared.

All ingredients are mixed for $20 \mathrm{~min}$, and the mixture then is stuffed into the natural casing. Samples are heat processed until they reached the internal temperature of $72{ }^{\circ} \mathrm{C}$. The sausages samples are then rinsed with cooled water and stored at $4{ }^{\circ} \mathrm{C}$ for 6 days.

\section{Lipid oxidation measurements (acid value, peroxide number, thiobarbituric acid reactive species)}

The acid value was determined by the batch titration with sodium hydroxide in the concentration in the presence of fenolftalein alcohol solution $[25,26]$. 3-5 $\mathrm{g}$ of the investigated forcemeat was weighted in the conic retort with the volume of $150-200 \mathrm{~cm}^{3}$ with the error of no more than $0,001 \mathrm{~g}$. The batch was heated on the water bath and after the addition of $50 \mathrm{~cm}^{3}$ of neutralized ether-alcohol mixture shaken. Then 3-5 drops of fenolftalein alcohol solution with the mass share of $1 \%$ were added. The received solution while shaking was titrated fast with potassium hydroxide solution with the molar 
concentration $0,1 \mathrm{~mol} / \mathrm{dm}^{3}$ till the distinct rose coloration appeared and kept for $1 \mathrm{~min}$. The acid number was calculated by the formula:

$$
\mathrm{X}=(\mathrm{V} \times \mathrm{K} \times 5,61) / \mathrm{m},
$$

where $\mathrm{V}$ - volume of potassium hydroxide solution, with the molar concentration 0,1 $\mathrm{mol} / \mathrm{dm}^{3}$, used for titration; $\mathrm{K}$ - correction to alkali solution for recalculation on the distinct $\left(0,1 \mathrm{~mol} / \mathrm{dm}^{3}\right)$ one; 5,61 - number of milligrams of potassium hydroxide, contained in 1 $\mathrm{cm}^{3}\left(0,1 \mathrm{~mol} / \mathrm{dm}^{3}\right)$ of solution; $\mathrm{m}$ - forcemeat batch mass, $\mathrm{g}$.

The method of PV determination is based on the batch extraction by the mixture of chloroform and icy acetic acid and further titration by the sodium hyposulfite solution with the previously added starch solution $[25,26] .0,8-1 \mathrm{~g}$ of a batch, weighted with accuracy of no more than $0,0002 \mathrm{~g}$ were placed in the conic retort with the stopper, melt on the water bath and $10 \mathrm{~cm}^{3}$ of chloroform and $10 \mathrm{~cm}^{3}$ of icy acetic acid were gently poured on the retort sides. $0,5 \mathrm{~cm}^{3}$ of saturated, freshly prepared potassium iodine solution was quickly added. The retort was closed with the stopper, the content was mixed by turning movements and put into the dark place for 3 minutes. Then $100 \mathrm{~cm}^{3}$ of distilled water with the previously added $1 \mathrm{~cm}^{3}$ of starch solution with the mass share of $1 \%$ was gently poured into the retort. After that it was titrated with sodium hyposulfite solution with the molar concentration of $0,01 \mathrm{~mol} / \mathrm{dm}^{3}$ until the blue coloration disappeared.

To verify the clearness of reagents the control determination without a batch was realized. The peroxide number was calculated by the formula:

$$
\mathrm{X}=[(\mathrm{V}-\mathrm{V} 1) \times \mathrm{K} \times 0,00127 \times 100 / \mathrm{m},
$$

where $\mathrm{V}$ - volume of sodium hyposulfite solution with the molar concentration 0,01 $\mathrm{mol} / \mathrm{dm}^{3}$, used for titration in the main experiment with the forcemeat batch, $\mathrm{cm}^{3}$; V1 volume of sodium hyposulfite solution $\left(0,01 \mathrm{~mol} / \mathrm{dm}^{3}\right)$, used for titration in the control experiment without a forcemeat batch, $\mathrm{cm}^{3} ; \mathrm{K}$ - coefficient of correction to sodium hyposulfite for recalculation on the distinct $\left(0,01 \mathrm{~mol} / \mathrm{dm}^{3}\right)$ solution; 0,00127 - number of grams of iodine, equivalent to $1 \mathrm{~cm}^{3}\left(0,01 \mathrm{~mol} / \mathrm{dm}^{3}\right)$ of sodium hyposulfite; $\mathrm{m}$ - mass of the studied forcemeat batch, $g$.

TBARS was determined by measuring the coloration intensity of the mixture of the studied sample distillate and thiobarbituric acid solution (1:1) after 35 minutes on the water bath on the spectrophotocolorimeter "Sрекоl-11" (Germany) at the wave length $535 \mathrm{~nm}$ [28].

$50 \mathrm{~g}$ of forcemeat batch were put into the porcelain mortar, $50 \mathrm{~cm}^{3}$ of distilled water were measured by the glass cylinder, added to the mortar and ground with the pestle into the uniform mixture. The prepared sample was quantitatively transferred into Kjeldahl retort, remains were washed away from the mortar with $47,5 \mathrm{~cm}^{3}$ of distilled water and then $2,5 \mathrm{~cm}^{3}$ of hydrochloric acid were added. The distillation was carried out in Kjeldahl apparatus, collecting $50 \mathrm{~cm}^{3}$ of distillate in the volumetric flask. $5 \mathrm{~cm}^{3}$ of distillate were taken, poured into the retort with the fitted stopper. After the addition of $5 \mathrm{~cm}^{3}$ of thiobarbituric acid, the retort was closed with the fitted stopper and heated on the boiling water bath for $35 \mathrm{~min}$. 
Simultaneously the control experiment was held, using $5 \mathrm{~cm}^{3}$ of distilled water instead of the distillate. Then the solutions were cooled in the cold running water for $10 \mathrm{~min}$, and the optic density at the wave length of $535 \pm 10 \mathrm{~nm}$ as to the control solution was measured.

The thiobarbituric acid reactive species, mg of MA (malonic aldehyde) / $\mathrm{kg}$ of the product, was calculated by the formula:

$$
\mathrm{X}=\mathrm{D} \times 7,8,
$$

where D - optic density of the solution; 7,8 - coefficient of proportional dependency of MA density on its concentration in the solution. This coefficient is a permanent value.

\section{Statistical analysis}

The absolute error of measurements was determined by Student criterion, the reliable interval $\mathrm{P}=0,95$, the number of repeatitions in calculations $-3-4$, the number of parallel tests of studied samples -3 .

\section{Results and discussion}

To characterize the effect of RE on the course of hydrolytic processes in the lipid fraction of the meat-containing sausages, the AV was determined, as shown in Fig. 1.

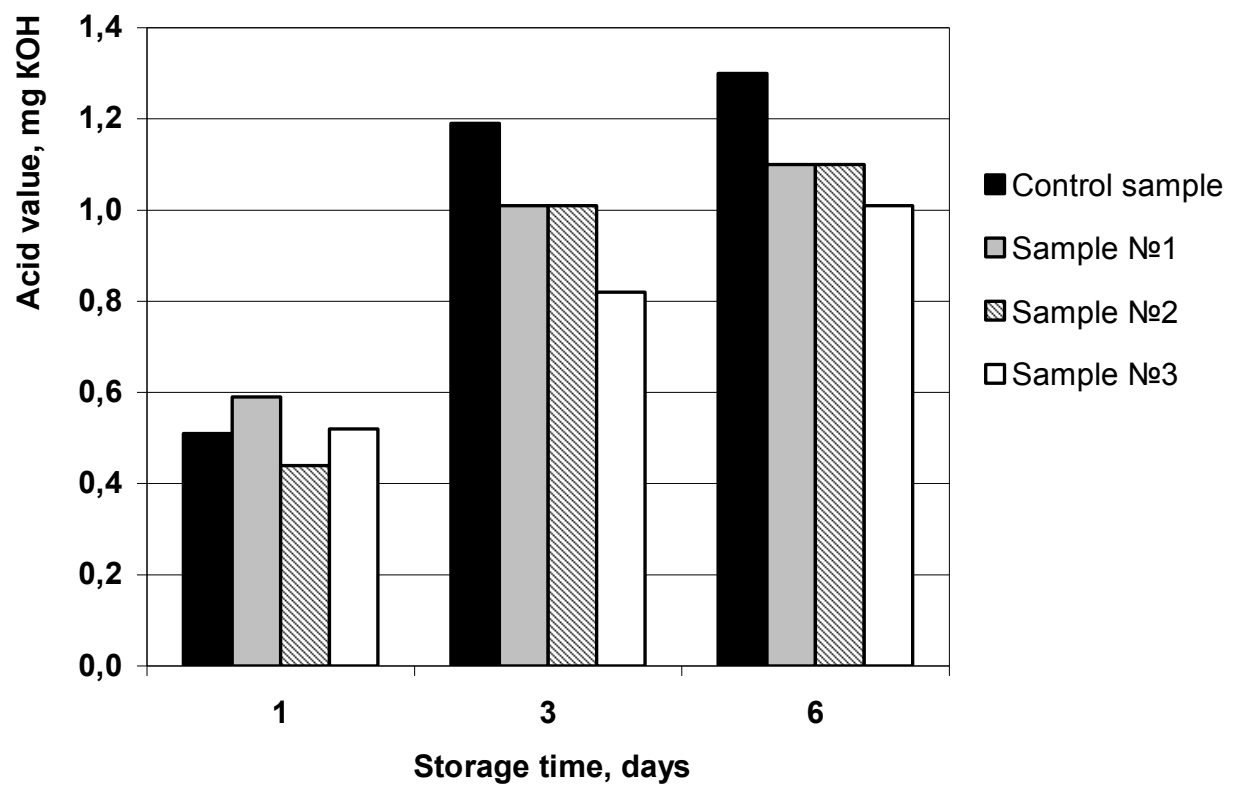

Figure 1. The dependence of the acid value on the concentration of the added rosemary extract, mg KOH 
Among the experimental samples, the smallest amount of free fatty acids was observed with rosemary extract concentration of $0.05 \%$. At the end of the storage period, after 6 days, the AV in the sample number 1 reached 1,095 $\pm 0,007 \mathrm{mg}$ of $\mathrm{KOH}$, in the sample number $2-1,105 \pm 0,007$, and in the third sample $-1,01 \pm 0,13$, which is $15-21 \%$ lower than in the control sample.

The obtained results indicate that the introduced antioxidant inhibits fat hydrolysis due to the high concentration of flavonoids in the extract. Sample 3 had the highest effectiveness.

The dynamics of the PV shift in the meat-containing sausages with duck meat is shown in Figure 2.

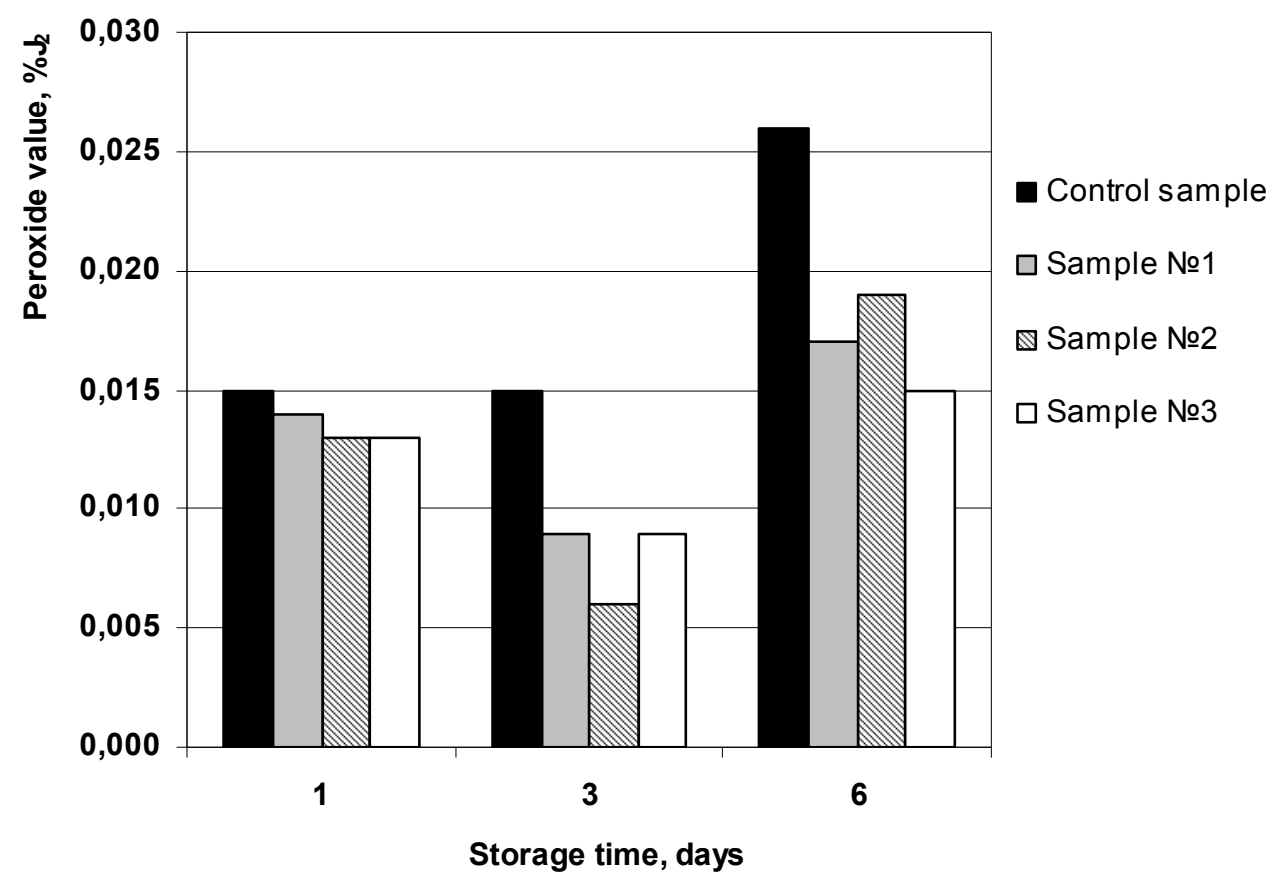

Figure 2. The dependence of the peroxide value on the concentration of the added rosemary extract, $\% \mathbf{J}_{2}$

The addition of rosemary extract helps slow down oxidative processes, as evidenced by the results of the research. Among the experimental samples, the PV increased more intensively in the sample without an additive. The largest stabilizing effect was produced by the concentration preparation used in sample 3. The PV in this sample on the expiration date was $0.015 \pm 0.001 \% \mathrm{~J}_{2}$, whereas in the control sample, this value was $0,026 \pm 0,002 \%$ $\mathrm{J}_{2}$, which is $57,69 \%$ higher.

The study of the dynamics of the peroxide value in the samples indicates that the rosemary extract contains the optimal ratio of biologically active compounds that actively contribute to the inhibition of lipid peroxide oxidation. The depression of deep lipid oxidation is due to the high content in the rosemary extract of carnosine and rosemary acids, the activity of which is twice as high as the activity of synthetic antioxidants [29]. 
The antioxidant action of the additives is also manifested in the accumulation of mono and di-aldehydes that react with 2-thiobarbituric acid. To determine the volume of secondary oxidation products accumulation on the last day of the fat samples storage, the thiobarbituric acid (TBARS) value of the fat was studied, and the TBARS results are presented in Fig. 3.

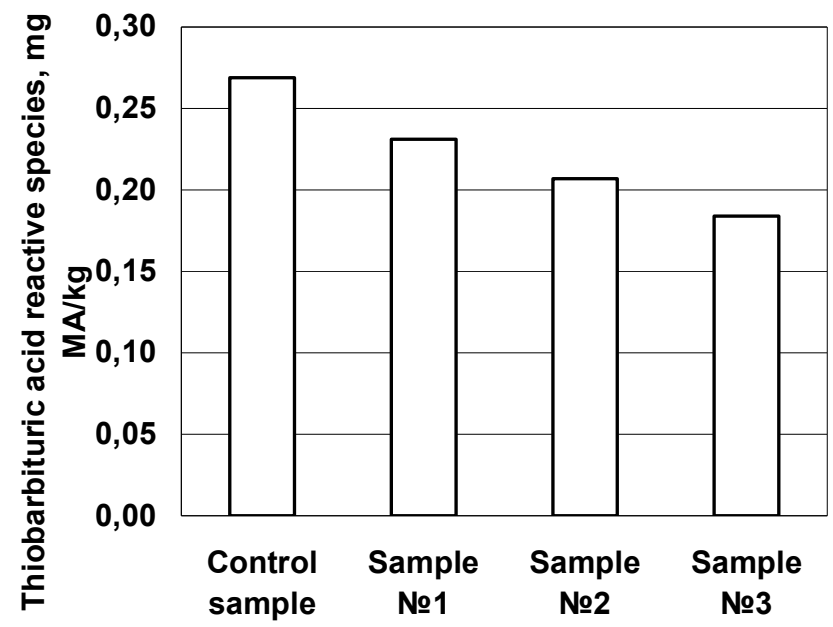

Figure 3. The influence of bioflavonoids of the rosemary extract on the accumulation of secondary products of oxidizing the lipids of the meat-containing sausages, mg MA/kg

Secondary oxidation products, namely, peroxides and hydroperoxides, are the carriers of unpleasant taste and odor of oxidized fats. The addition of RE helps slow down the accumulation of secondary oxidation products. At the end of the storage period, the amount of secondary oxidation products in the control sample was $0,269 \pm 0,04 \mathrm{mg} \mathrm{MA} / \mathrm{kg}$ of the finished product, whereas in the experimental samples it reached the following values: $0,231 \pm 0,03 \mathrm{mg} \mathrm{MA} / \mathrm{kg}$ in sample $1,0,207 \pm 0,03 \mathrm{mg} \mathrm{MA} / \mathrm{kg}$ in sample 2, and $0,184 \pm 0,04$ $\mathrm{mg} \mathrm{MA} / \mathrm{kg}$ in sample 3 .

The rosemary extract had the highest effectiveness at the concentration of $0.05 \%$ in sample 3, where the amount of malonic aldehyde in the sausage at the end of its shelf life was the lowest; $31,6 \%$ lower than in the control sample.

The research of the secondary oxidation products content allowed us to estimate the depth of the oxidative processes occurring in the specimens of the sausages while stored for 6 days at $+4{ }^{\circ} \mathrm{C}$. The concentration of the secondary oxidation products was the highest in the control sample, and in the experimental ones, the concentration of the added antioxidant additive reduced proportionally. It is known that the carnosic acid and carnosol of the rosemary extract are the active oxygen absorbers, preventing the formation of hydroperoxides and propanal [24, 29, 30].

The components of the rosemary extract make the joining of oxygen and glycerides impossible, thereby inhibiting the oxidative processes in minced meat. Carnosic acid and 
carnosol block peroxide radicals particularly effective in the systems based on the high content of lipid components.

The effectiveness of the antioxidant additive depended on the concentration, but in all experimental samples of meat-containing sausages, the concentration of malonic aldehyde was lower compared to the control product.

\section{Conclusions}

1.The conducted research has confirmed the high antioxidant activity of rosemary extract and the effective inhibition of the oxidation process of duck meat lipids.

2.The addition of the RE in the amount of $0,03-0,04 \%$ helps slow down the hydrolytic oxidation of the minced duck meat lipids by $15-21 \%$.

3.The addition of rosemary extract in the concentrations of $0,03-0,05 \%$ to the forcemeat mass contributes to the slowing of lipid peroxide oxidation in meat-containing sausages with duck meat. Peroxide value decreases by $26,92-57,69 \%$ depending on the concentration of the RE.

4.Stabilization of lipid peroxide oxidation in meat-containing sausages with duck meat as a consequence inhibits the formation of secondary oxidation products, which is confirmed by the results. The number of secondary oxidation products that react with tiobarbituric acid was the smallest at the end of the storage period of meat-containing sausages with musk duck meat with an RE concentration of $0.05 \%$ and amounted to $0.184 \pm 0.04 \mathrm{mg} \mathrm{MA} / \mathrm{kg}$, which is lower than in the control sample, by $31.6 \%$.

5.The largest effect was obtained with the rosemary extract concentration of $0.05 \%$, which reduces the oxidative deterioration of fat almost by two times.

\section{References}

1. Bertelsen G., Jakobsen M., Juncher D., Moller J., Kroger-Ohlsen M., Weber C., \& Skibsted L.H. (2000), Oxidation, shelf-life and stability of meat and meat products, Proceedings of the 46th international congress of meat science and technology, 4.IIL2, pp. 516-524.

2. Pasichnyj V.M., Zheludenko Ju.V. (2014), Perspektyva natural'nyh antyoksydantiv dlja vykorystannja v m'jasopererobnij galuzi, Zbirnyk naukovyh prac' HDUHT, 2(20), pp. 264-276.

3. Shahidi F. (1997), Natural Antioxidants. Chemistry, Health Effects and Applications, Champaign, Illinois, AOCS Press.

4. Ukrainets A., Pasichniy V., Zheludenko Yu., (2016), Plant extracts antioxidant properties for meat processing industry, Biotechnologia Acta, 2, pp. 19-27.

5. Nunez de Gonzalez M., Boleman R., Miller R., Keeton J., Rhee K. (2008), Antioxidant properties of dried plum ingredients in raw and precooked pork sausage, Journal of Food Science, 73, pp. 63-71.

6. Naveena, B., Sen, A., Vaithiyanathan, S., Babji, Y., \& Kondaiah, N. (2008), Comparative efficacy of pomegranate juice, pomegranate rind powder extract and BHT as antioxidants in cooked chicken patties, Meat Science, 89, pp. 304-308.

7. Lee C., Reed J., Richards M. (2006), Ability of various polyphenolic classes from cranberry to inhibit lipid oxidation in mechanically separated turkey and cooked ground pork, Journal of Muscle Foods, 17, pp. 248-266. 
8. Kandaswami C., Middleton E. (1994). Free radical scavenging and antioxidant activity of plant flavonoids, Adv. Exp. Med. Biol., 366, pp. 351-361.

9. Velasco V., Williams P. (2011), Improving meat quality through natural antioxidants, Chilean Journal of Agricultural Research, 71, pp. 313-322.

10. Fernandez-Lopez J., Zhi N., Aleson-Carbonell L., Perez-Alvarez J. A., Kuri V. (2005), Antioxidant and antibacterial activities of natural extracts: application in beef meatballs, Meat Science, 69, pp. 371-380.

11. Bozhko N., Tishhenko V., Pasichnij V. (2017), Ekstrakt zhuravlini v texnologiiy varenih kovbas z myasom vodoplavnoyi ptyci, Naukovij visnyk LNUVMBT imeni S.Z. Gzhyczkogo, 75, pp. 106-109.

12. Lara M.S., Gutierrez J.I., Tim'on M., Andr'es A.I. (2011). Evaluation of two natural extracts (Rosmarinus officinalis L. and Melissa officinalis L.) as antioxidants in cooked pork patties packed in MAP, Meat Science, 88, pp. 481-488.

13. Trindade R.A., Lima A., Andrade-Wartha E.R., Oliveira e Silva A.M., Mancini-Filho J, Villavicencio A.LC.H. (2009), Consumer's evaluation of the effects of gamma irradiation and natural antioxidants on general acceptance of frozen beef burger, Radiat Phys Chem, 78, pp. 293-300.

14. Sebranekab J.G, H.Sewalt V.J., Robbins K.L., Housera T.A. (2005), Comparison of a natural rosemary extract and BHA/BHT for relative antioxidant effectiveness in pork sausage, Meat Science, 69, pp. 289-296.

15. Rižnar K., Čelan Š., Knez Ž., ŠKKerget M., Bauman D. , Glaser R. (2006), Antioxidant and Antimicrobial Activity of Rosemary Extract in Chicken Frankfurters, Journal of Food Science, 71(7), pp. 425-429.

16. Mc.Bride N., Hogan S., Kerry J.P. (2007), Comparative addition of rosemary extract and additives on sensory and antioxidant properties of retail packaged beef, Internat. J.Food Science and Technology, 42, pp. 1201-1207.

17. Hernandez-Hernandez E., Ponce-Alquieira E, Jaramillo-Flores M., Guerrero-Legaretta I. (2009). Antioxidant effect rosemary and oregano extracts on TBARS and colour model raw pork batters. Meat Science, 81 (2), pp. 410-417.

18. Mitrofanov N.S., Makoveev I.I. (2006), Miaso ptitsy osnova dlia rasshireniia assortimenta miasnykh produktov, Miasnaia industriia, 4, pp. 26-29.

19. Makhonina V.N. (2016), Izuchenie morfologicheskogo i khimicheskogo sostava miasa potroshennykh tushek utok dlia opredeleniia ego sortnosti, Ptitsa i ptitseprodukty, 1, pp. 61-64.

20. Zalialieva D.R., Krishtafovich D.V., Krishtafovich V.I. (2011), Kachestvo miasa muskusnykh utok, Miasnaia industriia, 9, pp. 29-35.

21. Krishtafovich V.I., Zalialieva D.R. (2011), Issledovanie potrebitelskikh svoistv i pishchevoi tsennosti miasa muskusnykh utok, Tovaroved prodovolstvennykh tovarov, 6, pp. 23-27.

22. Kumar Y., Yadav D., Ahmad T., Narsaiah K. (2015), Recent Trends in the Use of Natural Antioxidants for Meat and Meat Products, Comprehensive Reviews in Food Science and Food Safety, 14, pp. 796-812.

23. Gupta A. D., Bansal V. K., Babu V., Maithil N. (2013), Chemistry, antioxidant and antimicrobial potential of nutmeg (Myristica fragrans Houtt), J. Genet. Engin. Biotechnol, 11, pp. 25-31.

24. Sisse Jongberg, Mari Ann Torngren, Annemarie Gunvig, Leif H. Skibsted, Marianne N. Lund (2013), Effect of green tea or rosemary extract on protein peroxidation in Bologna type sausages prepared from oxidatively stressed pork, Meat Science, 93, pp. $538-546$. 
25. Bozhko N., Tischenko V., Pasichnyi V., Marynin A., Polumbryk M. (2017), Analysis of the influence of rosemary and grape seed extracts on oxidation the lipids of Peking duck meat, Eastern-European Journal of Enterprise Technologies, 4/11( 88 ), pp. 4-9.

26. Zhuravskaia N.K., Gutnik B.E., Zhuravskaia N.A. (2001), Tekhnokhymycheskyi kontrol proyzvodstva miasa s miasoproduktov, Kolos, Moscow.

27. Nikitin B.I., Nikitina N.B. (1983), Pererabotka pticy, krolikov i proizvodstvo pticeproduktov, Moscow.

28. Bozhko N. Tischenko V., Pasichnyi V., Marynin A., Polumbryk M. (2017), Study of oxidation processes in duck meat with application of rosemary and grape seed extracts, EUREKA: Life Sciences, 4, pp. 10-15.

29. Brewer M. S. (2011), Natural antioxidants: Sources, compounds, mechanisms of action, and potential applications, Comprehens. Rev. Food Science and Food Safety, 10, pp. 221-247.

30. Brewer S. (2008), Preserving beef quality with natural antioxidants, Research knowledge management, 12, pp.1-14. 